\title{
Peran Asthma Control Test [ACT] dalam Tata laksana Mutakhir Asma Anak
}

\section{Heda Melinda Nataprawira}

Subbagian Respirologi Bagian Ilmu Kesehatan Anak Fakultas Kedokteran Universitas Padjadjaran RS Dr. Hasan Sadikin, Bandung

\begin{abstract}
Asma adalah penyakit kronik yang sampai saat ini belum dijumpai obat yang bisa menyembuhkannya. Maka tidak ada istilah sembuh untuk asma, namun asma dapat terkontrol. Strategi tata laksana asma saat ini lebih menitikberatkan pada mengontrol asma secara klinis daripada menentukan klasifikasi derajat penyakit serta tata laksana serangan akut. Untuk mengontrol asma diperlukan suatu alat sederhana dan praktis yang dapat digunakan dalam praktek sehari-hari dan salah satunya adalah asthma control test (ACT). Untuk anak usia 4-11 tahun, ACT memuat empat pertanyaan yang dapat diisi oleh anak dan tiga pertanyaan yang diisi orangtua apabila skor $>20$ dinyatakan asma terkontrol. Untuk usia $\geq 12$ tahun terdapat lima pertanyaan yang diisi oleh anak. Skor 25 berarti asma anak terkontrol total, sedangkan skor 20-24 dinyatakan on target yang berarti asma terkontrol baik tetapi belum mencapai terkontrol total. Apabila skor < 20 menunjukkan off target yang berarti asma tidak terkontrol. Setelah asma terkontrol, pengawasan secara berkala tetap diperlukan. (Sari Pediatri 2007; 9(4):239-45).
\end{abstract}

Kata kunci: Asthma control test, asma anak

A

sma adalah penyakit kronik yang sangat kompleks dan hingga saat ini belum ada obat yang dapat dapat menyembuhkannya. Namun, asma tidak dapat sembuh, penyakit asma dapat terkontrol (tidak pernah kambuh). ${ }^{1-4}$

\footnotetext{
Alamat korespondensi

Heda Melinda Nataprawira, dr., SpA(K), M. Kes Subbagian Respirologi Bagian Ilmu Kesehatan Anak Fakultas Kedokteran Universitas Padjadjaran RS Dr. Hasan Sadikin, Bandung Jl. Pasteur 38, Bandung Telp/Fax.022-2034426/2035957 e-mail: heda_1155@yahoo.com
}

Penyakit asma dapat mengenai semua usia yang apabila asma tidak terkontrol akan menyebabkan individu mempunyai keterbatasan dalam melakukan aktivitas sehari-hari. ${ }^{1-4}$ Tujuan tata laksana asma sudah dijelaskan dalam global strategy for asthma management and prevention tahun 1995 yang kemudian direvisi pada tahun 2002, ${ }^{2}$ namun pada tahun 2004 strategi tersebut direvisi kembali dengan lebih menitikberatkan pada kontrol asma secara klinis daripada penentuan klasifikasi derajat penyakit. ${ }^{3}$ Laporan global initiative for asthma (GINA) tahun berikutnya hingga tahun 2006 juga tetap menitikberatkan pada kontrol asma dan bukan lagi pada tata laksana serangan akut. ${ }^{4}$ Ini 
berarti bahwa anak harus bebas gejala atau gejala asma menjadi sangat berkurang termasuk gejala malam hari, tidak terdapat keterbatasan dalam melakukan aktivitas, tidak lagi menggunakan obat pereda (rescue medications), fungsi paru menunjukkan nilai normal atau mendekati normal, sangat jarang mengalami serangan asma, tidak pernah lagi masuk unit gawat darurat, dan bebas dari efek samping obat. Apabila hal tersebut tercapai, maka anak mencapai total kontrol. ${ }^{4}$

Pedoman pengobatan asma sudah meluas disebarkan, ${ }^{1-4}$ namun hasil penelitian menunjukkan bahwa banyak pasien asma tidak mendapat pengobatan semestinya (undertreated) sehingga berisiko mengalami ekaserbasi asma. ${ }^{5}$ Oleh sebab itu untuk memberikan penilaian kontrol asma yang optimal diperlukan suatu metode atau alat yang sederhana dan praktis yang dapat mengidentifikasi asma yang tidak terkontrol. ${ }^{4,6-8}$

\section{Klasifikasi asma}

Berbagai upaya telah dilakukan untuk mengelompokkan asma berdasarkan etiologi, terutama dengan memperhatikan penyebab lingkungan yang menjadi pencetus, namun klasifikasi seperti ini mengalami keterbatasan. Upaya untuk mengenal penyebab lingkungan terhadap asma harus merupakan bagian dari penilaian awal sehingga penghindaran terhadap agen pencetus dapat menjadi bagian dari tata laksana asma. $^{1-4}$

\section{Derajat penyakit asma}

Dalam GINA 2004, klasifikasi derajat penyakit asma menurut tingkat gejala, keterbatasan aliran udara, dan fungsi paru dikategorikan ke dalam empat kategori yaitu asma intermiten, persisten ringan, persisten sedang, dan persisten berat. ${ }^{3}$ Sejak tahun 2006 klasifikasi derajat penyakit, dianjurkan hanya digunakan untuk kepentingan penelitian. ${ }^{4}$ Dengan mengacu pada GINA 2004, Pedoman Nasional Asma Anak Indonesia tahun 2004 membagi klasifikasi derajat penyakit asma menjadi asma episodik jarang, asma episodik sering, dan asma persisten. ${ }^{9}$

Klasifikasi asma lain berdasarkan derajat serangan yaitu serangan ringan, sedang, berat, dan mengancam jiwa. ${ }^{3,4,9}$ Klasifikasi ini bermanfaat pada saat awal penanganan pasien. Harus diingat bahwa derajat serangan asma mengikutsertakan derajat penyakit serta respons terhadap pengobatan. Oleh karena itu asma dengan gejala dan obstruksi saluran respiratorik berat masuk dalam klasifikasi persisten berat pada awalnya, apabila menunjukkan respons baik terhadap pengobatan maka dikelompokkan sebagai asma persisten sedang. Selain itu, derajat penyakit bukan sesuatu kondisi yang menetap pada seorang pasien asma, tetapi dapat berubah dalam beberapa bulan atau beberapa tahun. Dengan pertimbangan ini, walaupun klasifikasi derajat penyakit asma tersebut berdasarkan pendapat para pakar dan bukan berbasis bukti, namun masih mempunyai manfaat untuk tujuan penelitian. Keterbatasan menggunakan klasifikasi derajat penyakit adalah kemampuan memprediksi jenis obat yang diperlukan serta respons yang terjadi pada pasien terhadap pengobatan yang diberikan. Untuk tujuan ini, penilaian berkala dari kontrol asma menjadi lebih relevan dan berguna. ${ }^{3,4,8}$

\section{Kontrol asma}

Secara umum, istilah kontrol dapat diartikan sebagai pencegahan penyakit atau bahkan penyembuhan namun kedua istilah ini tidak berlaku untuk asma. Istilah kontrol untuk asma adalah pengendalian terhadap manifestasi penyakit. Idealnya hal ini tidak hanya berlaku untuk manifestasi klinis tetapi juga nilai laboratorium dan gambaran patofisiologis penyakit dengan pemeriksaan seperti biopsi endobronkial dan pengukuran eosinofil sputum dan ekshalasi nitric oxide. ${ }^{4}$ Namun karena biaya dan/atau ketidaksediaan pemeriksaan tersebut maka direkomendasikan bahwa pengobatan ditujukan untuk mengendalikan gambaran klinis penyakit.

Karakteristik kontrol asma yang merupakan rating adalah asma yang terkontrol (controlled), terkontrol sebagian (partly controlled), dan tak terkontrol (uncontrolled) (Tabel 1). Pembagian dan rating ini belum divalidasi. Kontrol sempurna asma pada umumnya dicapai dengan obat-obatan yang harus dipertahankan untuk jangka waktu lama dengan memperhatikan keselamatan pasien akibat obat yang diberikan, efek samping, dan biaya pengobatan yang diperlukan untuk mencapai tujuan ini. ${ }^{4}$

Alat atau metode yang sudah tervalidasi untuk menilai kontrol klinis asma dibuat dalam variabel atau item dengan nilai numerik untuk membedakan derajat 
Tabel 1. Derajat kontrol asma ${ }^{4}$

\begin{tabular}{llll}
\hline Karakteristik & $\begin{array}{l}\text { Terkontrol } \\
(\text { semua yang } \\
\text { di bawah) }\end{array}$ & $\begin{array}{l}\text { Terkontrol Sebagian } \\
(\text { salah satu kejadian } \\
\text { dalam seminggu }\end{array}$ & Tidak Terkontrol \\
\hline Gejala sehari-hari & $\begin{array}{l}\text { Tidak ada } \\
(\leq 2 \mathrm{x} / \text { minggu })\end{array}$ & $>2 \mathrm{x} /$ minggu & \\
$\begin{array}{l}\text { Keterbatasan aktivitas } \\
\text { Gejala nokturnal/terbangun malam }\end{array}$ & $\begin{array}{l}\text { Tidak ada } \\
\text { Tidak ada }\end{array}$ & $\begin{array}{l}\text { Ada } \\
\text { Ada }\end{array}$ & $\geq 3$ kondisi asma \\
Perlu obat pereda/reliever & $\begin{array}{l}\text { Tidak perlu } \\
(\leq 2 \mathrm{x} / \text { minggu })\end{array}$ & $>2 \mathrm{x} /$ minggu & $\begin{array}{l}\text { yang terjadi dalam } \\
\text { Normal }\end{array}$ \\
$\begin{array}{l}\text { Fungsi paru }\left(\mathrm{PEF} \text { atau } \mathrm{FEV}_{1}\right)^{\ddagger} \\
\text { Eksaserbasi }\end{array}$ & $\begin{array}{l}<0 \% \text { nilai prediksi } \\
\text { Tidak ada }\end{array}$ & $\geq 1 \mathrm{x} /$ tahun* & $\begin{array}{l}\text { Sekali dalam salah } \\
\text { satu minggu }\end{array}$ \\
\hline
\end{tabular}

* Setiap terjadi eksaserbasi harus dinilai ulang kecukupan pengobatan pencegahan yang sedang diberikan

$\dagger$ Eksaserbasi pada salah satu minggu membuat minggu tersebut minggu asma tidak terkontrol

$\neq$ Tes fungsi paru tidak dapat diandalkan pada anak usia $\leq 5$ tahun

kontrol yang berbeda. Contoh alat yang sudah tervalidasi adalah Asthma Control Test/ACT, ${ }^{6,7}$ Asthma control questionnaire/ACQ ${ }^{10}$ Asthma therapy assessment questionnaire/ATAQ, ${ }^{11}$ dan Asthma control scoring system/ACSS. ${ }^{12}$ Tidak semua alat tersebut menyertakan pengukuran fungsi paru. Alat ini dipromosikan penggunaannya tidak hanya dalam penelitian tetapi juga untuk penanganan pasien sehari-hari. Salah satu alat atau metode untuk menilai kontrol asma secara klinis tanpa menyertakan pengukuran fungsi paru adalah ACT.4,6,7

\section{Penanganan dan pencegahan asma}

Asma mempunyai pengaruh yang nyata baik terhadap anak, keluarga, dan lingkungan. Meskipun tidak ada obat yang dapat menyembuhkan asma, namun penanganan yang sesuai yaitu dengan mengikutsertakan kerjasama antara dokter dan pasien/keluarga dapat mencapai kontrol penyakit ini. Tujuan penanganan asma yang berhasil adalah untuk mencapai dan mempertahankan tanpa gejala, mempertahankan tingkat aktivitas normal termasuk olah raga, mempertahankan fungsi paru menjadi normal, mencegah eksaserbasi asma, mencegah efek samping obat asma, dan mencegah mortalitas asma. Penelitian klinis menunjukkan bahwa asma dapat dikontrol secara efektif dengan cara menekan dan menghilangkan peradangan serta mengobati bronkokonstriksi dan gejala yang berkaitan. Selain itu, intervensi dini dengan menghentikan pajanan terhadap faktor risiko yang mensensitisasi saluran respiratorik dapat membantu memperbaiki kontrol asma dan mengurangi perlunya obat.

Rekomendasi penanganan asma dibuat dalam beberapa komponen yang saling berkaitan yaitu ${ }^{4}$ 1). Mengembangkan kerjasama dokter/pasien, 2). Mengenal dan mengurangi pajanan faktor risiko, 3). Menilai, memberikan pengobatan, dan monitor asma,

4). Penanganan eksaserbasi asma.

\section{Komponen 1: mengembangkan kerjasama dokter/ pasien}

Penanganan asma yang efektif memerlukan hubungan pasien asma dengan tenaga profesional kesehatan dan orangtua/pengasuh. Tujuan hubungan ini agar pasien asma dapat memperoleh pengetahuan, kepercayaan diri, dan kemampuan untuk berperan dalam penanganan asma mereka. Hubungan ini dibentuk dan diperkuat saat pasien dan profesional kesehatan berdiskusi dan menyetujui tujuan pengobatan, rencana tindakan, serta secara berkala menilai pengobatan dan derajat kontrol asma. Pendekatan ini disebut dengan penanganan mandiri dan terbukti mengurangi morbiditas asma baik pada orang dewasa maupun anak. Edukasi merupakan bagian integral dari semua interaksi antara profesional kesehatan dan pasien/ orangtua. Komunikasi yang baik mempunyai arti 
penting sebagai dasar untuk kepatuhan pengobatan. Hasil kajian sistematik mengemukakan pentingnya peranan edukasi dan strategi penanganan asma yang dipandu (guided self management) dalam penatalaksanaan asma. ${ }^{13}$

\section{Komponen 2: mengenal dan mengurangi pajanan faktor risiko}

Untuk meningkatkan kontrol asma dan mengurangi perlunya obat-obatan, pasien harus melakukan tindakan untuk menghindari faktor risiko yang menyebabkan gejala asma. Banyak pasien asma yang bereaksi terhadap berbagai faktor yang terdapat di sekeliling mereka sehingga menghindari faktor pencetus tersebut seringkali tidak mungkin. Oleh karena itu, obat-obatan untuk mempertahankan kontrol asma mempunyai peran yang penting karena pasien sering kurang perhatian terhadap faktor risiko saat asma mereka terkontrol.

Aktivitas fisik seringkali merupakan penyebab gejala asma timbul, namun pasien jangan sampai menghindari aktivitas berolahraga. Gejala asma dapat dicegah dengan obat agonis $\beta_{2}$-kerja cepat sebelum melakukan olahraga, dan sebagai alternatif lain bisa digunakan obat golongan leukotrine modifier. Tindakan penghindaran perlu dilakukan untuk meningkatkan kontrol asma dan mengurangi perlunya obat-obatan antara lain menghindar dari asap rokok, orangtua tidak boleh merokok, menghindarkan obat-obatan, makanan, dan bahan aditif bila diketahui dapat menyebabkan gejala, cuci sprei dan selimut setiap minggu dalam air panas.,

\section{Komponen 3: menilai, memberikan pengobatan, dan monitor asma ${ }^{4}$}

Tujuan tata laksana asma adalah mencapai dan mempertahankan kontrol klinis dapat dicapai oleh pasien dengan menggunakan strategi intervensi farmakologis yang dikembangkan dari hubungan antara pasien/keluarga dan dokter. Tiap pasien ditempatkan pada satu dari lima langkah tata laksana yang tergantung pada derajat kontrol dan pengobatan disesuaikan dengan siklus berkesinambungan menurut status kontrol asma. Siklus ini menilai kontrol asma (Gambar 1), pengobatan untuk mendapatkan kontrol, dan monitoring untuk mempertahankan kontrol.

\section{Menilai kontrol asma}

Asthma control test (ACT) adalah salah satu dari beberapa alat penilai kontrol asma. Berdasarkan usia anak maka terdapat ACT untuk anak usia 4-11 tahun (Lampiran1) dan anak usia $\geq 12$ tahun (Lampiran2). Asma yang tidak terkontrol dapat berlanjut sehingga terjadi eksaserbasi sehingga langkah segera harus diambil untuk kembali mendapatkan kontrol (Komponen 4). Asthma control test untuk anak usia 4-11 tahun dilakukan bersama-sama dengan orang tua dan hasilnya didiskusikan dengan dokter anak. Untuk anak usia $\geq 12$ tahun dan dewasa apabila didapatkan skor 25 berarti asma sudah tercapai total kontrol, sedangkan apabila skor antara 20-24 menunjukkan on target yang berarti asma terkontrol baik tetapi belum mencapai total kontrol. Apabila skor $<20$ menunjukkan off target yang berarti asma tidak terkontrol (Lampiran 1 dan 2)

\section{Pengobatan untuk mendapatkan kontrol}

Tidak banyak penelitian untuk pengobatan asma anak usia $\leq 5$ tahun, namun pengobatan terbaik untuk mengontrol asma kelompok usia ini adalah glukokortikosteroid inhalasi dan pada langkah 2, direkomendasikan dosis-rendah glukokortikosteroid inhalasi sebagai obat controller awal. Apabila pengobatan ini tidak dapat mengendalikan gejala, peningkatan dosis glukokortikosteroid inhalasi adalah merupakan pilihan terbaik. ${ }^{4,14}$ Untuk anak usia $>5$ tahun, setiap anak ditempatkan dalam salah satu dari langkah pengobatan (Gambar 1). Pada setiap langkah pengobatan, obat reliever harus diberikan apabila terjadi eksaserbasi untuk mengatasi gejala secara cepat (akan tetapi hati-hati mengenai berapa banyak obat reliever yang digunakan pasien-pemakaian secara rutin atau dosis yang meningkat menunjukkan bahwa asma tidak terkontrol secara baik). Pada Langkah 2 hingga 5, pasien juga membutuhkan satu atau lebih obat controller untuk mencegah timbulnya gejala maupun serangan. ${ }^{4}$

Bagi sebagian besar pasien yang baru didiagnosis asma atau belum mendapat pengobatan, maka pengobatan harus dimulai pada Langkah 2 (atau bila pasien sangat simtomatik, mulai dari Langkah 3). Bila asma tidak terkontrol pada regimen pengobatan yang sedang berlangsung, maka langkah pengobatan 


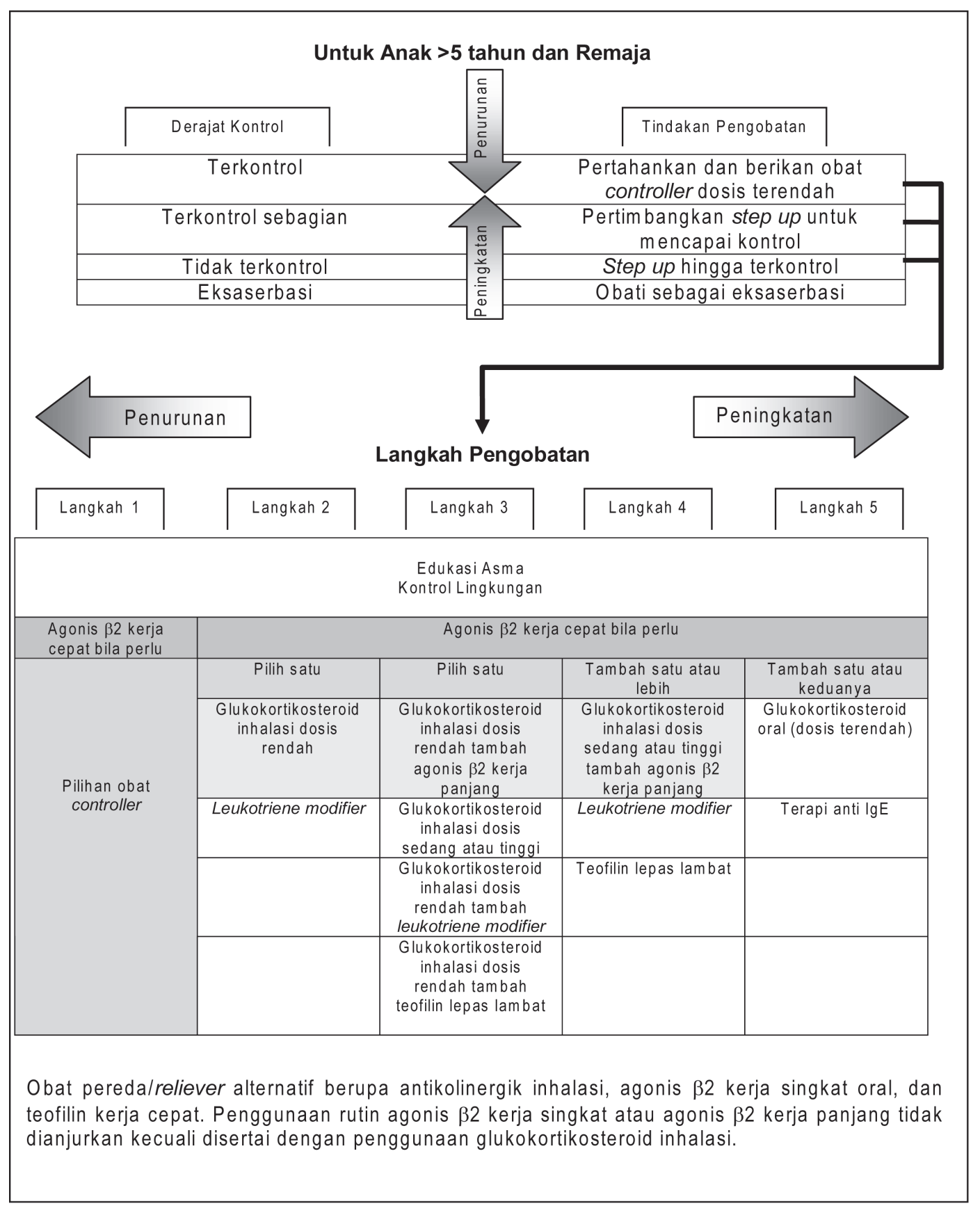

Gambar 1. Pendekatan tata laksana berdasarkan asma terkontrol ${ }^{4}$

harus dinaikkan hingga tercapai kontrol. Berbagai obat controller dan reliever untuk asma yang dikemukakan adalah merupakan panduan dalam penanganan asma, namun ketersediaan obat lokal dan kondisi masing-masing pasien yang me- nentukan pengobatan yang akan diberikan. ${ }^{4}$ Cara pengobatan dengan inhalasi lebih disarankan karena dapat menghantarkan obat secara langsung ke dalam saluran respiratorik sebagai target kerja obat, sehingga terjadi efek terapeutik maksimal dengan efek samping sistemik minimal. ${ }^{4}$ 


\section{Monitoring untuk mempertahankan kontrol ${ }^{4}$}

Monitoring penting untuk mempertahankan kontrol dan mendapatkan langkah serta dosis terendah untuk menekan biaya dan keamanan akibat pemberian obat. Biasanya pasien diperiksa setiap satu hingga tiga bulan setelah kunjungan pertama, dan selanjutnya setiap tiga bulan. Bila terjadi eksaserbasi, pemantauan harus dilakukan dalam dua minggu hingga satu bulan.

Penyesuaian pengobatan adalah sebagai berikut

- Asma tidak terkontrol dengan regimen pengobatan yang diberikan, maka langkah pengobatan perlu dinaikkan dan umumnya perbaikan terlihat dalam satu bulan. Teknik penggunaan obat, kepatuhan, dan penghindaran faktor risiko harus dinilai dulu. Bila asma terkontrol sebagian, maka perlu dipertimbangkan untuk menaikkan langkah pengobatan, tergantung pada pilihan obat yang lebih efektif, keamanan dan biaya pilihan pengobatan, serta kepuasan pasien dengan derajat kontrol yang didapat.

- Asma kontrol dapat dipertahankan selama paling sedikit tiga bulan, turunkan langkah pengobatan secara bertahap yang bertujuan untuk mempertahankan kontrol.

Pengawasan tetap diperlukan bahkan setelah kontrol tercapai dan karena asma merupakan penyakit yang bervariasi, maka pengobatan harus diatur secara berkala dalam hal respons terhadap hilangnya kontrol seperti terlihat berupa gejala yang memburuk atau timbulnya eksaserbasi. Apabila anak tidak berespons terhadap pengobatan yang diberikan atau bila asma tetap tidak terkontrol setelah dilakukan pengobatan pada Langkah 3, maka perlu dilakukan konsultasi dengan spesialis respirologi anak. ${ }^{4}$

\section{Komponen 4: penanganan eksaserbasi ${ }^{4}$}

Eksaserbasi asma (serangan asma) adalah episode perburukan yang progresif dari gejala sesak, batuk, wheezing, dada tertekan, atau kombinasi dari gejala tersebut. Beberapa hal yang perlu diperhatikan adalah bahwa anak/remaja berisiko mengalami kematian akibat asma dan anak yang perlu diberi perhatian lebih ketat dan dianjurkan untuk berobat pada awal eksaserbasi mereka dengan riwayat asma yang mengancam nyawa, pernah dirawat di rumah sakit atau instalasi gawat darurat karena asma dalam satu tahun terakhir, sedang menggunakan atau baru saja menghentikan pemakaian glukokortikoid oral, tergantung kepada agonis beta- $\beta_{2}$ inhalasi kerja-cepat, atau riwayat tidak patuh terhadap rencana penanganan asma. Pasien harus segera dibawa berobat apabila terjadi serangan asma berat. Pasien sesak saat istirahat, membungkuk ke depan, bicara hanya berbentuk kata dan bukan kalimat (bayi tidak mau menetek), gelisah, mengantuk atau bingung, bradikardi, atau laju napas $>30$ kali/menit; suara wheezing keras atau menghilang, laju nadi $>160 /$ menit pada bayi, $>120 /$ menit pada anak 1-2 tahun dan $>110 /$ menit pada anak 2-8 tahun, peak expiratory rate $<60 \%$ dari nilai prediksi bahkan setelah terapi awal, anak kelelahan, tidak segera memberikan respons terhadap obat bronkodilator awal dan bertahan minimal 3 jam, tidak terjadi perbaikan dalam 2 hingga 6 jam setelah dimulai terapi glukokortikosteroid, dan terjadi perburukan lebih lanjut.

\section{Kesimpulan}

Pedoman tata laksana dan pencegahan asma untuk anak telah disebarluaskan di seluruh dunia dan bahkan sudah diadaptasi di Indonesia, namun panduan pengobatan asma saja tidak cukup untuk menjamin penilaian kontrol asma yang tepat. Untuk mengidentifikasi asma yang tidak terkontrol atau terkontrol sebagian, diperlukan suatu alat atau metode yang praktis dan sederhana. Salah satu metode yang dapat dipakai untuk menilai kontrol asma dan tidak menggunakan pemeriksaan fungsi paru adalah Asthma Control Test (ACT). Untuk anak, ACT sudah divalidasi dan dikemas untuk anak usia 4-11 tahun dan $\geq 12$ tahun. Pengawasan tetap diperlukan bahkan setelah kontrol tercapai, dan karena asma merupakan penyakit kronik dengan gejala bervariasi, maka pengobatan harus dipantau secara berkala dalam hal respons terhadap hilangnya kontrol.

\section{Daftar Pustaka}

1. National Institutes of Health, National Heart, Lung and Blood Institute. National asthma education and prevention program. expert panel. Clinical practice guidelines: expert panel report 2-guidelines for the diagnosis and management of asthma. Bethesda: National Insitutes of Health, National Heart, Lung, and Blood Institute. Publication no. 97-4051; 1997. 
2. Global Initiative for Asthma (GINA). Global strategy for asthma management and prevention: NHLBI/WHO workshop report. Bethesda: National Institutes of Health, National Heart, Lung and Blood Institute. Publication No. 02-3659; 2002.

3. Global Initiative for Asthma (GINA). Global strategy for asthma management and prevention. Updated 2004, 2004.

4. Global Initiative For Asthma (GINA). Global Strategy for asthma management and prevention. Revised 2006; 2006.

5. Fuhlbrigge AL, Adams RJ, Guilbert TW Grant E, Lozano P, Janson SL, dkk. The burden of asthma in the United States: level and distribution are dependent on interpretation of the national asthma education and prevention program guidelines. Am J Respir Care. 2002; 166:1044-9.

6. Nathan RA, Sorkness CA, Kosinski M, Schatz M, Li JT, Marcus P, dkk. Development of the asthma control test: a survey for assessing asthma control. J Allergy Clin Immunol. 2004; 113:59-65.

7. American Lung Association. Asthma Control Test. 2003. Didapat dari: http://www. asthma control com/. (Diakses pada 24 Desember 2006).
8. Bateman ED, Boushey HA, Bousquet J, Busse WW, Clark TJH, Pauwels RA, dkk. Can guideline-defined asthma control be achieved. The gaining optimal asthma control study. Am J Respir Crit Care Med. 2004; 170:836-44.

9. Unit Koordinasi Kerja Pulmonologi. Pengurus Pusat Ikatan Dokter Anak Indonesia (UKK Pulmonologi-PP IDAI). Pedoman Nasional Asma Anak. Jakarta: 2004.

10. Juniper EF, Buist AS, Cox FM, Ferrie PJ, King DR. Validation of a standardized version of The Asthma Quality of Life Questionnaire. Chest 1999; 115:1265-70.

11. Vollmer WM, Markson LE, O’Connor E, Sanocki LL, Fitterman L, Berger M, dkk. Association of asthma control with health care utilization and quality of life. Am J Respir Crit Care Med. 1999; 160:1647-52.

12. Boulet LP, Boulet V, Milot J. How should we quantify asthma control? A proposal. Chest. 2002; 122:2217-23.

13. Guevara JP, Wolf FM, Grum CM, Clark NM. Effects of educational interventions of self management of asthma in children and adolescents: systematic review and meta-analysis. BMJ. 2003; 326:1308-9.

14. Guilbert TW, Morgan WJ, Zeiger RS, Mauger DT, Boehmer SJ, Szefler SJ, dkk. Long-term inhaled corticosteroids in preschool children at high risk for asthma. N Engl J Med. 2006; 354:1985-97. 